\title{
Cytotoxicity of Essential Oil of Chenopodium ambrosioides L against Human Breast Cancer MCF-7 Cells
}

\author{
Wu Jia-liang, Ma Dan-wei, Wang Ya-nan, Zhang Hong, He Bing, Li Qun, Zou \\ Zhi-yan and Feng Jing \\ College of Life Science, Sichuan Normal University, Chengdu 610101, China.
}

*For correspondence: Email: danwei10ma@163.com; Tel: +86-13699478376

\begin{abstract}
Purpose: To investigate the cytotoxic activity of the essential oil of Chenopodium ambrosioides $L$. against human breast cancer MCF-7 cells.

Methods: Cytotoxicity was characterized by $50 \%$ inhibition $\left(I_{50}\right)$ of human breast cancer cell lines (MCF-7) using 3-(4,5-dimethylthaizol-2-yl)-2,5-diphenyltetrazolium bromide (MTT) assay. Apoptosis was analysed by Hoechst33258 staining and DNA ladder. MCF-7 cellular superoxide dismutase (SOD), catalase (CAT) vitality and malondialdehyde (MDA) content were evaluated.

Results: The essential oil was cytotoxic to MCF-7 cell line. A dose- and time-dependent inhibition was observed with $I C_{50}$ values of $18.75,9.45$ and $10.50 \mu \mathrm{g} / \mathrm{ml}$ at 6,24 and $48 \mathrm{~h}$, respectively. Analyses by Hoechst33258 staining and DNA ladder indicate that the essential oil induced apoptosis. SOD vitality significantly decreased $(p<0.05)$ by $51 \%$ when the concentration of the essential oil increased from 1.25 to $12.5 \mu \mathrm{g} / \mathrm{ml}$ while CAT vitality significantly increased $(p<0.05)$ by $71 \%$ when essential oil concentration was similarly increased. The MDA content of each treatment group, when compare to control, did not show any significant difference $(p<0.05)$.

Conclusion: The essential oil of C. ambrosioides was cytotoxic to MCF-7 cell line and induced apoptosis.
\end{abstract}

Keywords: Chenopodium ambrosioides L., Essential oil, Cytotoxicity, Apoptosis, Breast cancer, MCF-7 cells.

Tropical Journal of Pharmaceutical Research is indexed by Science Citation Index (SciSearch), Scopus, International Pharmaceutical Abstract, Chemical Abstracts, Embase, Index Copernicus, EBSCO, African Index Medicus, JournalSeek, Journal Citation Reports/Science Edition, Directory of Open Access Journals (DOAJ), African Journal Online, Bioline International, Open-J-Gate and Pharmacy Abstracts

\section{INTRODUCTION}

There are a large number of major secondary metabolites of natural origin with a variety of potential applications [1-4]. Essential oils function basically as primary metabolites. It has many biological activities including allelopathy [2], insecticide resistance [3], antibacterial [4] and antifungal [5]. In the last two decades, there has been increasing interest in the pharmacological activity of essential oils [6].
Several works on essential oils that show their anti-cancer properties have been reported $[7,8]$.

Mexican tea (Chenopodium ambrosioides $\mathrm{L}$ ) is an annual or perennial herb native to tropical America. It is one of the most severely invasive weeds in China. This weed first invaded Danshuei Township of Taipei County in 1864. Currently, it commonly distributes in most areas of China, and produces a great threat to the local ecological system [9]. There is no doubt that 
utilization of $C$. ambrosioides is an effective approach control the spread of this weed. There have been a lot of studies about its essential oil applications [2-4]. However, there is no report on the inhibition of cancer cell proliferation by the essential oil of $C$. ambrosioides. Only few studies have shown that the hydroalcohol extract of $C$. ambrosioides leaves increased cellular recruitment, phagocytic ability and nitric oxide production [10].

Since C. ambrosioides essential oil has been shown to induce cancer cell death, this work sought to investigate the cytotoxic activity of the essential oil on human breast cancer cell lines (MCF-7). The study further examined whether the anti-cancer mechanism of the essential oil involves induction of apoptosis. In addition, the possible mechanism of $C$. ambrosioides essential oil-induced apoptosis was assessed.

\section{EXPERIMENTAL}

\section{Plant material and essential oil distillation}

Whole plant of C. ambrosioides was collected from Chengdu in Sichuan Province (China) in November 2011. A voucher specimen (Collector no. 004) and deposited in the Herbarium of Sichuan Normal University, Chengdu, Sichuan Province, China. The samples were authenticated by $\mathrm{Dr}$. Ma Danwei of Sichuan Normal University.

The essential oil of $C$. ambrosioides was extracted by steam distillation [11]. The extracted oil was dried over anhydrous sodium sulphate and the purified oil was filled in small vials, tightly sealed and stored at $4{ }^{\circ} \mathrm{C}$ until further analysis.

\section{Cell lines and culture}

Human breast cancer line MCF-7 was cultured in RPMI-1640 supplemented with $10 \%$ fetal calf serum. Cells were grown and maintained at 37 ${ }^{\circ} \mathrm{C}$ in a humidified atmosphere with $5 \% \mathrm{CO}_{2}$.

\section{Cytotoxicity analysis by the MTT assay}

The essential oil was dissolved in DMSO to obtain a concentration of $50 \mathrm{mg} / \mathrm{ml}$ which served as stock solution. The stock volume was serially diluted with DMSO (99.5\%) to obtain solutions of desired concentrations. In vitro cytotoxicity of $C$. ambrosioides essential oil was determined using 3-(4,5-dimethylthaizol-2-yl)-2,5-diphenyltetrazolium bromide (MTT) assay. MCF-7 cells were harvested using trypsin and counted using a haemocytometer. To $1 \times 10^{4}$ cells/well, $100 \mu \mathrm{l}$ of essential oil was seeded in 96 wells. The plates were incubated for $24 \mathrm{~h}$ (at $37{ }^{\circ} \mathrm{C}$ in an atmosphere of $\left.5 \quad \% \quad \mathrm{CO}_{2}\right)$. Then test concentrations $(100 \mu \mathrm{L} /$ well $)$ were added to the wells containing cells. The plates were incubated for a further 6,24 and $48 \mathrm{~h}$ after addition of test material. The final concentration of DMSO in the culture medium was maintained at $1.0 \%(\mathrm{v} / \mathrm{v})$ to avoid toxicity of the solvent. After 6,24 and $48 \mathrm{~h}$, $20 \mu \mathrm{L}$ of $5 \mathrm{mg} / \mathrm{ml}$ MTT in PBS (phosphate buffer solution) was added to each well and then incubated for at $37{ }^{\circ} \mathrm{C}$ in an incubator. The medium was removed and $150 \mu \mathrm{L}$ of dimethylsulfoxide (DMSO, Sigma) was added to each well. After shaking for $10 \mathrm{~min}$, the absorbance was measured at $490 \mathrm{~nm}$. Growth inhibition (GI) was calculated formulas in Eq 1.

$$
\mathrm{GI}(\%)=\{(1-\mathrm{At} / \mathrm{Ac})\} 100
$$

where At is the absorbance of the test sample and Ac the absorbance of the control.

\section{Hoechst DNA staining test}

Briefly, MCF-7 cells $\left(5 \times 10^{5}\right.$ cells $\left./ \mathrm{ml}\right)$ were treated with different concentrations of test sample (essential oil) for 6, 24 or 48 h. After the specified time, the processed cells were fixed by $4 \%$ polyformaldehyde at $4{ }^{\circ} \mathrm{C}$ for 10 to $20 \mathrm{~min}$ and washed twice with PBS. Then the cells were stained with $5 \mu \mathrm{g} / \mathrm{mL}$. Hoechst 33258 for $10 \mathrm{~min}$, washed three times with PBS and dried in the dark at room temperature. Lastly, the samples were viewed under a fluorescence microscope (TE2000-U, Nikon, China).

\section{DNA ladder assay}

Apoptosis was assessed by electrophoresis of extracted genomic DNA from treated MCF-7 cells as described previously with some modification. Briefly, using varying concentrations $(0-50 \mu \mathrm{g} / \mathrm{mL})$ of the test sample (essential oil) MCF-7 cells $(1 \times 106$ cells $/ \mathrm{mL})$ were harvested after treatment for $24 \mathrm{~h}$, centrifuged at $2000 \mathrm{rpm}$ for $5 \mathrm{~min}$ and washed with PBS. The cells were suspended in $250 \mu \mathrm{L}$ of lysis buffer (10 mM EDTA, $50 \mathrm{mM}$ Tris- $\mathrm{HCl}, 0.5$ $\%$ SDS) at $55{ }^{\circ} \mathrm{C}$ for $15 \mathrm{~min}$. The lysed cells were incubated with $10 \mu \mathrm{l}$ of RNase at $55{ }^{\circ} \mathrm{C}$ for 90 min and digested with $10 \mu \mathrm{l}$ of proteinase-K (20 $\mathrm{mg} / \mathrm{ml}$ ) at $55{ }^{\circ} \mathrm{C}$ for $1 \mathrm{~h}$. DNA was extracted twice with isopyknic chloroform: isoamyl alcohol (24:1) for $1 \mathrm{~min}$ and centrifuged at $12,000 \mathrm{rpm}$ for 5 min. Finally, DNA was precipitated from the aqueous phase with 0.1 volume of $2 \mathrm{M} \mathrm{NaCl}$ and 2.5 volumes of chilled ethanol, and kept at $20{ }^{\circ} \mathrm{C}$ overnight. The precipitated DNA was centrifuged at $12,000 \mathrm{rpm}$ for $10 \mathrm{~min}$ and dissolved in TrisEDTA buffer ( $\mathrm{pH}$ 8.0). DNA was subjected to electrophoresis in $1.5 \%$ agarose gel at $50 \mathrm{~V}$ for 
90 min. The gel was photographed using Gel documentation system (Bio-Rad, Alfred Noble Drive, China).

\section{Determination of antioxidant activity}

MCF-7 cells $\left(5 \times 10^{5}\right.$ cells $\left./ \mathrm{ml}\right)$ were treated with varying concentrations $(0-50 \mu \mathrm{g} / \mathrm{mL})$ of the test sample (essential oil) for 6,24 or $48 \mathrm{~h}$. After the specified time, the processed cells were used in the detection of superoxide dismutase (SOD), catalase (CAT) vitality and malondialdehyde (MDA) content. Experimental procedures were conducted according to the kit manufacturer's instructions. SOD, CAT and MDA method were measured by A003-1 kit, A007-1 kit, A003-4 kit, Nanjing Jiancheng Bioengineering Institute, Nanjing, respectively.

\section{Statistical analysis}

All the data were expressed as mean \pm standard deviation (SD). Statistical analysis was carried out using PASW (version 18.0) software. Oneway ANOVA was used for multiple comparisons. A $p$ value of $<0.05$ was considered significant.

\section{RESULTS}

\section{Cytotoxicity of essential oil of ambrosioides on MCF-7 cancer cells}

The effect of essential oil from C. ambrosioides on MCF-7 cells, as assessed by MTT assay, is shown in Fig 1. A dose and time-dependent inhibition was observed with $\mathrm{IC}_{50}$ values of $18.75,9.45$ and $10.50 \mu \mathrm{g} / \mathrm{ml}$ at 6,24 and $48 \mathrm{~h}$, respectively.

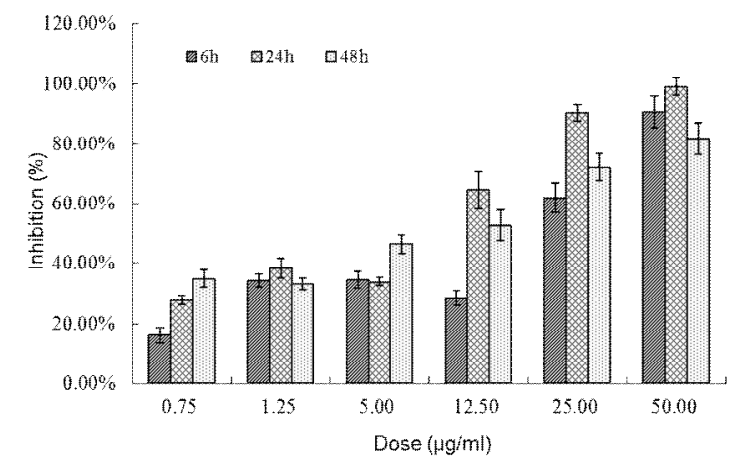

Fig 1: Inhibition of MCF-7 cell growth by $C$. ambrosioides essential oil. Error bars denote standard deviation; $\mathrm{n}=3$

\section{Effect of essential oil on apoptosis}

The results of the use of fluorescence microscopy to visualize MCF-7 cell nucleus after exposure to the essential oil are shown in Fig 2. Compared with control cells (Fig 2-A, D and G), the cells appeared to show condensation and/or fragmentation of nuclei with essential oil concentration of $50 \mu \mathrm{g} / \mathrm{ml}$ at $6 \mathrm{~h}$. However, the phenomenon was observed in cells treated with $12.5 \mu \mathrm{g} / \mathrm{ml}$ essential oil at 24 and $48 \mathrm{~h}$.

The essential oil $(\mu \mathrm{g} / \mathrm{ml})$

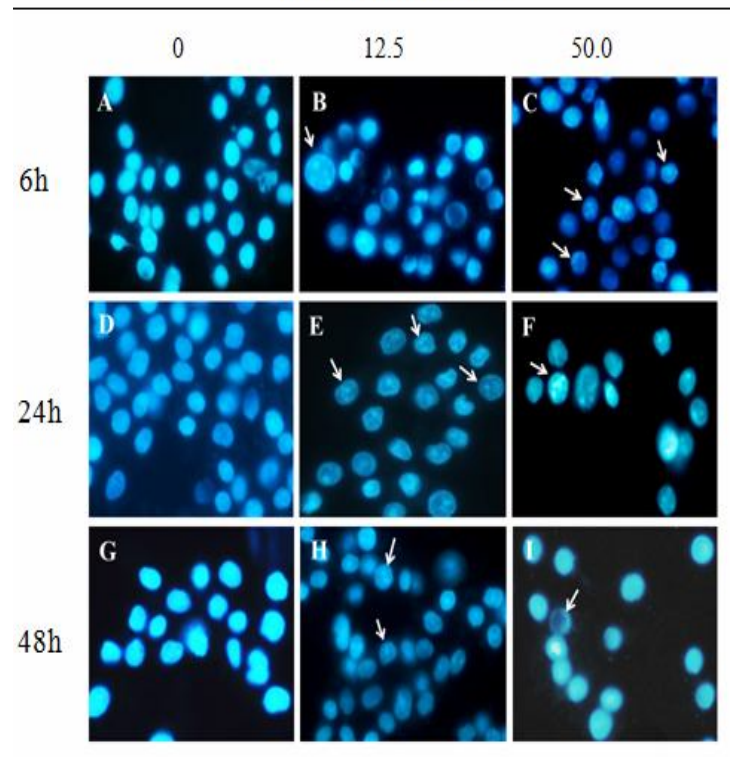

Fig 2: Morphology of MCF-7 cells. Note: Arrows point to apoptotic cells showing fragmented and/or condensed nuclei

\section{DNA fragmentation}

The DNA of the MCF-7 cells treated with the essential oil from C. ambrosioides exhibited double-strand damage as observed with agarose gel electrophoresis (Fig. 3).

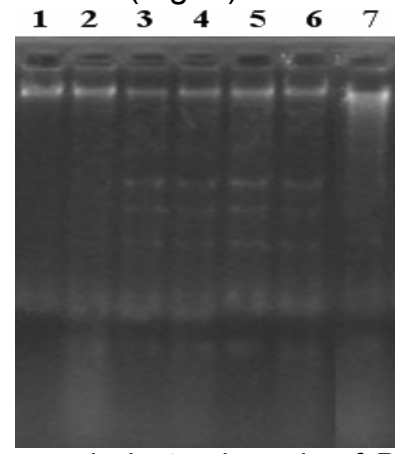

Fig 3: Agarose-gel electrophoresis of DNA extracted from MCF-7 cells untreated and treated with different concentration of $C$. ambrosioides essential oil for $24 \mathrm{~h}$. Lane 1 = control; lane $2=0.75 \mu \mathrm{g} / \mathrm{mL}$ oil; lane $3=$ $1.25 \mu \mathrm{g} / \mathrm{mL}$; lane 4 = $5 \mu \mathrm{g} / \mathrm{mL}$ oil; lane $5=12.5 \mu \mathrm{g} / \mathrm{mL}$; lane $6=25 \mu \mathrm{g} / \mathrm{mL}$; lane $7=50 \mu \mathrm{g} / \mathrm{mL}$

Genomic DNA was isolated from the cells exposed to different concentration of the essential oil for $24 \mathrm{~h}$. Efficient induction of apoptosis was observed at $1.25-25 \mu \mathrm{g} / \mathrm{mL}$ essential oil treatment by formation of a distinct DNA ladder. The phenomenon of cell death in 
which DNA is a stage of dispersion appeared after treatment with $50 \mu \mathrm{g} / \mathrm{mL}$ essential oil.

\section{Antioxidant activity}

The data for antioxidant activity of the essential oil is shown in Figs $4-6$ for superoxide dismutase (SOD), catalase (CAT) and malondialdehyde (MDA) tests, respectively.

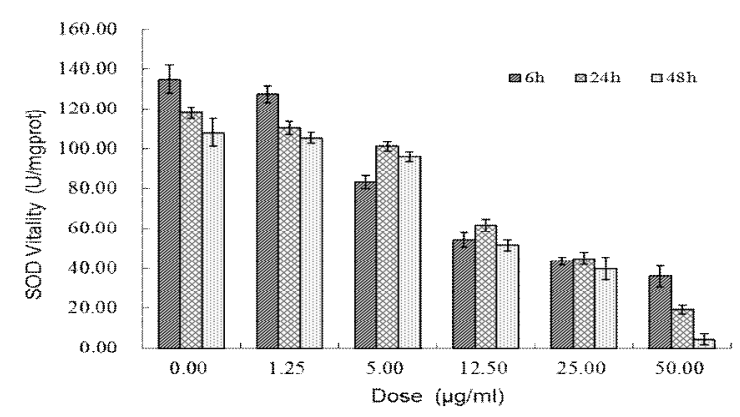

Fig 4: Effect of $C$. ambrosioides essential oil treatment on cellular SOD activity in MCF-7 cells

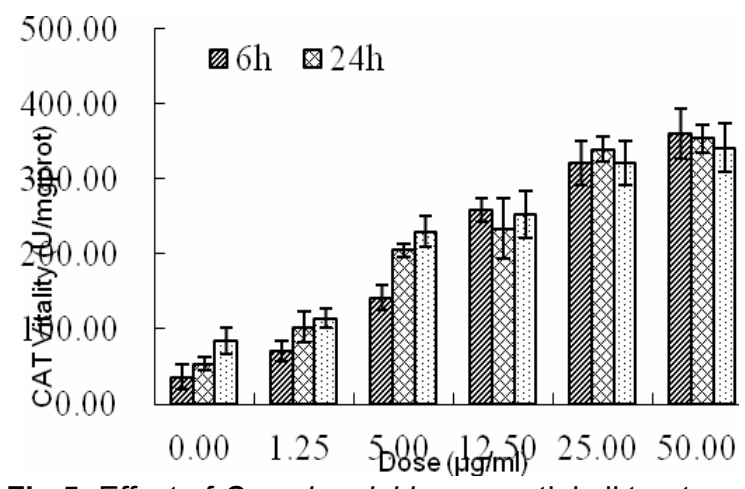

Fig 5: Effect of $C$. ambrosioides essential oil treatment on cellular CAT activity in MCF-7 cells

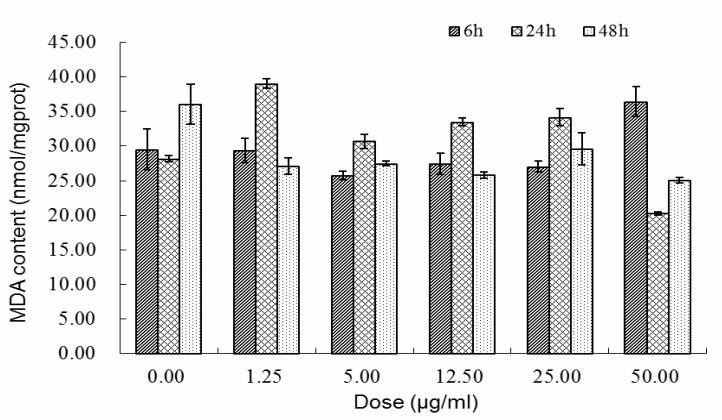

Fig 6: Effects of C. ambrosioides essential oil treatment on MDA content in MCF-7 cells

As seen in Fig 4, MCF-7 cellular SOD activity has a negative correlation with essential oil concentration and processing time. $C$. ambrosioides essential oil induced a dosedependent decrease in cellular SOD activity (51 $\%)$ but increase in CAT activity $(71 \%)$ as shown in Fig 5. These changes are significant $(p<$ 0.05 ). However, essential oil treatment did not result in significant changes in MDA content between treatment groups $(p<0.05$, Fig 6$)$.

\section{DISCUSSION}

In recent years, considerable attention has been focused on identifying naturally occurring substances capable of inhibiting, retarding, or reversing the process of multistage carcinogenesis $[6-8,13]$. In the present study, we examined whether or not the essential oil of $C$. ambrosioides has any potential in cancer chemoprevention using MCF-7 human breast cells.

The essential oil inhibited cell proliferation and was cytotoxic in a concentration- and timedependent manner in MCF-7 cells. Minimum $\mathrm{IC}_{50}$ was appeared at $24 \mathrm{~h}$. Compared to another study [12], the $\mathrm{IC}_{50}$ of the essential oil was lower, suggesting that the essential oil could exert strong anti-proliferative effect in MCF-7 cells at low dose.

Recently attention has focused on the manipulation of apoptosis processes in the treatment and prevention of cancer $[7,13,16]$. An essential oil from Capparis spinosa L. has been shown to induce apoptosis in human colon carcinoma cell line, HT-29 [6]. The essential oil from C. ambrosioides induced morphological alterations typical of apoptotic process, membrane blebbing, chromatin condensation, etc. This observation suggests the presence of increased number of apoptotic cells. DNA ladder is one of the most commonly used techniques for confirmation of apoptosis. The data showed internucleosomal DNA breakdown, leading to DNA fragmentation as expected for apoptosis cells. Thus, C. ambrosioides essential oil decreased cell survival by the induction of DNA fragmentation.

In order to confirm the possible mechanism of $C$. ambrosioides essential oil induction MCF-7 cells apoptosis, we investigate the involvement of antioxidant activity in the essential oil induced apoptosis. When the body is under a certain pressure, it will produce excess free radicals [14]. However, excess production of free radical will exacerbate oxidative damage to proteins, lipids and DNA and even lead to cell death $[12,15]$. The antioxidant data indicate that the essential oil is a weak antioxidant in MCF-7 cells. A previous study also found that the essential oil of A. tsao-ko exerted weak antioxidant activity against HepG2 [16]. Thus, the mechanism of induction of MCF-7 cell apoptosis may not be by oxidative damage. 
Two major signaling cascades, extrinsic and $t$ intrinsic pathways, lead to apoptosis $[12,17]$. The extrinsic pathway is triggered by interaction of cell-death factors with their cognate receptors, resulting in activation of caspase-8, which subsequently activates caspase- 3 . The intrinsic pathway is mainly triggered by non-receptor stimuli that regulate the level of proteins of the Bcl-2 family $[13,18]$. Increase in the levels of Bax and/or decrease in Bcl-2 lead to loss of MMP and release of pro-apoptotic factors such as cytochrome c from mitochondria to the cytosol, resulting in activation of caspase- 9 and subsequent activation of caspase-3 $[13,17]$. Therefore, one pathway can be amplified by crosstalk with another pathway. Therefore, the mechanism which the essential oil of $C$. ambrosioides reduced the MCF-7 cells apoptosis needs further investigation.

\section{CONCLUSION}

This work demonstrates that the essential oil of C. ambrosioides is cytotoxic to MCF-7 cells by a mechanism related to apoptosis, and that it is a weak antioxidant. Further studies are needed to determine the effective constituents of the oil and to elucidate their roles in achieving cytotoxicity. The mechanism by which the essential oil induces cell apoptosis also requires further investigation.

\section{ACKNOWLEDGEMENT}

This work was financially supported by a grant from National Natural Science Foundation of China (no. 31370549), the Education Office of Sichuan Province and Sichuan Normal University in China.

\section{REFERENCES}

1. Rajesh K, Ajay KM, Dubeya NK, Tripathib YB. Evaluation of Chenopodium ambrosioides oil as a potential source of antifungal, antiaflatoxigenic and antioxidant activity. Int J Food Microbiol 2007; 115(2): 159-164.

2. Wang JR, Ma DW, Tang L. Allelopathy of Volatile Oil from Chenopodium ambrosioides $L$. on Receptors. Southwest China Journal of Agricultural Sciences 2009; 22(3): 777-780.

3. Ketzis JK, Taylor A, Bowman DD, Brown DL, Warnick LD, Erb HN. Chenopodium ambrosioides and its essential oil as treatments for Haemonchus contortus and mixed adult-nematode infections in goats. Small Ruminant Res 2002; 44(3): 193-200.

4. Owolabi, MS, Lajide L, Oladimeji MO, Setzer WN, Palazzo $M C$, Olowu RA, Ogundajo A. Volatile constituents and antibacterial screening of the essential oil of Chenopodium ambrosioides L. growing in Nigeria. Nat Prod Commun 2009; 4(7): 989-992.

5. Carolina MJ. Composition and Antifungal Activity of the Essential Oil of the Brazilian Chenopodium ambrosioides L. J Chem Ecol 2008; 34: 1213-1218.

6. Tea KB, Ingrid S, Kerstin S, Laura SC, Giuseppe R. The anticarcinogenic potential of essential oil and aqueous infusion from caper (Capparis spinosa L.). Food Chem 2012, 132: 261-267.

7. Sylvestre M, Pichette A, Longtin A, Nagau F, Legault J. Essential oil analysis and anticancer activity of leaf essential oil of Croton flavens L. from Guadeloupe. J Ethnopharmacol 2006; 103: 99-102.

8. Sousa AC, Gattass CR, Alviano DS, Alviano CS, Blank $A F$, Alves $P B$. Melissa officinalis $L$. essential oil: antitumoral and antioxidant activities. J Pharm Pharmacol 2004; 56: 677-681.

9. Wang Y, Tang SG, Chen QM, Zhou GQ, Zhou GF, Wang WL, Peng YL. Studies on seed germination and storage of the invasive harmful species Chenopodium ambrosioides. Weed Sci 2007, 3: 1013.

10. Cruz GVB., Pereira PVS, Patrício FJ, Costa GC, Sousa SM, Frazão JB, Aragão-Filho WC, Maciel MCG, Silva $L A$, Amaral FMM, et al. Increase of cellular recruitment, phagocytosis ability and nitric oxide production induced by hydroalcoholic extract from Chenopodium ambrosioides leaves. J Ethnopharmacol 2007; 111(1): 148-154.

11. Meng $Q H$, Huang HJ, Liu Y, Liu XG, Wei SH, Zhang CX. Chemical compositions and allelopathic potential of volatile oil from Sorghum halepense (L.) Pers.. Acta Phytophylacica Sinica 2009; 36(3): 277-282.

12. Selvi MT, Thirugnanasampandan $R$, Sundarammal $S$. Antioxidant and cytotoxic activities of essential oil of Ocimum canum Sims. from India. Journal of Saudi Chemical Society 2012 online.

13. Woo CC, Loo SY, Gee V, Yap CW, Sethi G, Kumar AP, Tan KHB. Anticancer activity of thymoquinone in breast cancer cells: Possible involvement of PPAR-y pathway. Biochem Pharmacol 2011; 82: 464-475.

14. Stohs SJ. The role of free radicals in toxicity and disease. Journal of basic and clinical physiology and pharmacology 2011; 6(3-4): 205-228.

15. Maridonneau PI, Harpey C. Effect of trimetazidine on membrane damage induced by oxygen free radicals in human red cells. Brit J Clin Pharmaco 2012; 20(2): 148-151.

16. Yang Y, Yang Y, Yan RW, Zou GL. Cytotoxic, apoptotic and antioxidant activity of the essential oil of Amomum tsao-ko. Bioresource Technol 2010; 101: 4205-4211.

17. Brenner D, Mak TW. Mitochondrial cell death effectors. Curr. Opin. Cell. Biol 2009; 21: 871-877.

18. Youle RJ, Strasser $A$. The BCL-2 protein family: opposing activities that mediate cell death. Nat. Rev. Mol. Cell. Biol. 2008; 9: 47-59. 